\title{
PENYULUHAN PENGELOLAAN AIR BERSIH KEPADA MASYARAKAT DESA SIMPANG WARGA LUAR RT 02 SECARA DARING MENGGUNAKAN MEDIA WHATSAPP GROUP
}

\author{
Husaini'), Agung Waskito'), Angga Antoni'), Helmina'), Vinny Aziza') \\ 1)Program Studi Kesehatan Masyarakat, Fakultas Kedokteran, Universitas Lambung Mangkurat, Banjarbaru, \\ Kalimantan Selatan, Indonesia \\ Corresponding author : Angga Antoni \\ E-mail : anggaantoni29@gmail.com
}

Diterima 08 Juni 2021, Direvisi 10 Juli 2021, Disetujui 12 Juli 2021

\begin{abstract}
ABSTRAK
Air merupakan salah satu kebutuhan pokok yang sangat dibutuhkan manusia dalam kehidupan seharihari. Air merupakan permasalahan global yang terjadi di hampir seluruh lapisan masyarakat, termasuk di komunitas RT.02 Desa Simpang Warga Luar Kecamatan Aluh-Aluh Kabupaten Banjar dimana pengetahuan dan kemauan masyarakat masih rendah serta perilaku masyarakat yang keliru dalam mengelola air bersih. Masyarakat kurang memiliki pengetahuan mengenai pengelolaan air bersih, banyak masyarakat mengunsumsi air mentah dan menganggap tidak akan terjadi masalah pada kesehatannya jika mengonsumsi air mentah dikarenakan dampak tidak terjadi secara langsung pada kesehatan. Upaya yang dapat dilakukan untuk menanganai permasalahan tersebut adalah dengan memberikan edukasi melalui poster, booklet dan video pada masyarakat mengenai pengelolaan air bersih. Tujuan dari kegiatan tersebut adalah untuk menyebarluaskan informasi mengenai tata cara pengelolaan air bersih yang tepat, penyimpanan air dengan benar, dan kandungan e-coli atau bahan berbahaya lain yang memberikan dampak negatif bagi tubuh yang nantinya akan dirampungkan dalam sebuah informasi berupa poster, booklet dan juga video menggunakan media Whatsapp Group, sehingga diharapkan terjadinya peningkatan pengetahuan serta perubahan sikap dan perilaku masyarakat dalam pengelolaan air. Peningkatan pengetahuan akan diukur secara kuantitatif dengan membandingkan sebelum dan setelah mendapatkan intervensi dengan menggunakan uji wilcoxon. Berdasarkan hasil pelaksanaan intervensi pada 15 responden diketahui bahwa peningkatan pengetahuan sebanyak $8.98 \%$. Hasil uji mendapaktan nilai p 0,014 yang dapat diinterpretasikan terdapat perbedaan yang signifikan antara sikap responden pada saat pre-test maupun post-test mengenai pengelolaan air. Hasil ini diharapkan dapat memberikan persepsi yang baru bagi masyarakat agar dapat menerapkan pengelolaan air sesuai dengan syarat penggunaan air bersih.
\end{abstract}

Kata kunci: edukasi; pengelolaan air; menyebarluaskan informasi.

\begin{abstract}
Water is one of the basic needs that humans need in everyday life. Water is a global problem that occurs in almost all levels of society, including in the community of RT.02 Simpang Warga Luar Village, AluhAluh District, Banjar Regency where knowledge and willingness of the community are still low and people's behavior is wrong in managing clean water. The community lacks knowledge about clean water management, many people consume raw water and assume that there will be no problems with their health if they consume raw water because the impact does not occur directly on health. Efforts that can be made to deal with these problems are to provide education through posters, booklets and videos to the community regarding clean water management. The purpose of this activity is to disseminate information regarding proper clean water management procedures, proper water storage, and the content of e-coli or other hazardous materials that have a negative impact on the body which will later be completed in an information in the form of posters, booklets and also videos using Whatsapp Group media, so it is hoped that there will be an increase in knowledge and changes in people's attitudes and behavior in water management. The increase in knowledge will be measured quantitatively by comparing before and after getting an intervention using the Wilcoxon test. Based on the results of the intervention on 15 respondents, it is known that the increase in knowledge is $8.98 \%$. The test results obtained a p value of 0.014 which can be interpreted as a significant difference between the attitudes of respondents at the pre-test and post-test regarding water management. These results are expected to provide a new perception for the community so that they can implement water management in accordance with the requirements for using clean water.
\end{abstract}


Keywords: education; water management; disseminating information.

\section{PENDAHULUAN}

Dalam menjalani kehidupan kebutuhan dasar masyarakat adalah air. Seperti halnya menurut data Foogden dan Wood tahun 2009, kebutuhan masyarakat dunia terhadap air berkisar 20 liter per hari, yang mana 4 liter untuk konsumsi dan sisanya untuk kebutuhan lainnya seperti memasak, mandi dan sebagainya. Masalah yang dihadapi hampir di seluruh dunia merupakan kesediaan air minum. Kualitas air yang rendah akan menurunkan probabilitas meninggalnya balita sebesar 1,3 juta per tahun sesuai dengan data yang tertulis pada UNICEF. Menurut data Badan Pusat Statistik tahun 2015, rata-rata air bersih di setiap kabupaten hanya tercapai $49 \%$ dan sisanya tak layak konsumsi. Pemenuhan kebutuhan hidup masyarakat di suatu negara sangat mempengaruhi indeks pembangunan manusia (IPM) terhadap kurangnya air yang layak untuk dikonsumsi (Saputra \& Nur, 2019).

Seiring dengan perkembangan zaman, maka pemerintah daerah membangun sebuah perusahaan pengelolaan air untuk melakukan pelayanan untuk sumber air bersih dipasok dari perusahaan daerah air minum (PDAM). Kehadiran PDAM diatur melalui Undangundang Republik Indonesia No.5 tahun 1962 tentang perusahaan daerah. PDAM dibentuk sebagai kesatuan usaha milik pemerintah daerah yang memberikan jasa pelayanan, penyelenggaraan kemanfaatan umum di bidang air minum dan menumpuk pendapatan (Latief, 2019). Perusahaan daerah air minum (PDAM) merupakan perusahaan daerah sebagai sarana penyedia air bersih yang diberi tanggung jawab untuk mengembangkan dan mengelola sistem penyedian air bersih serta melayani semua kelompok konsumen (Noor, Supriyanto \& Rhomadhona, 2019).

Ketersediaan air di dunia tidak pernah berkurang bahkan dapat dikatakan berlimpah, tetapi yang dapat di konsumsi oleh manusia hanya sekitar $5 \%$ saja, sedangkan dengan tingginya tingkat modernisasi menyebabkan menurunnya kuliatas air yang $5 \%$ sehingga semakin sedikit jumlah air bersih yang dapat di konsumsi masyarakat (Irawan, Pamungkas \& Arhami, 2018). Berdasarkan Peraturan Menteri Kesehatan No.32 tahun 2017 tentang standar baku mutu kesehatan lingkungan dan persyaratan kesehatan air menyatakan bahwa air minum yang sehat harus memenuhi persyaratan fisik, kimia dan biologi. Beberapa persyaratan tersebut antara lain air harus jernih atau tidak keruh, tidak berwarna, rasanya tawar, $\mathrm{pH}$ netral, tidak mengandung bakteri pathogen seperti escherechia coli (Pontororing, Pinontoan \& Sumampouw, 2019).

Berdasarkan hasil diagnosa komunitas terdapat 3 masalah utama kesehatan yang perlu disosialisasikan kepada masyarakat sekaligus didiskusikan untuk menentukan permasalahan yang menjadi masalah prioritas untuk ditangani. Adapun ketiga permasalahan tersebut ialah pengelolaan sampah (86\%), penggunaan jamban (64\%) dan kualitas air minum (38\%). Hingga ditemukan masalah utama pada Desa Simpang warga luar RT 02 Kecamatan Aluh-Aluh adalah pengelolaan air bersih, sehingga menarik untuk dilakukannya pengabdian. Setelah dimusyawarakan lebih lanjut dengan masyarakat setempat diperoleh bahwa prioritas masalah yang dipilih masyarakat yaitu terkait pengelolaan air bersih, walaupun data kualitas air minum hanya $38 \%$ tetapi masyarakat berpendapat hal ini harus segera diselesaikan khususnya air minum yang sangat erat kaitannya dengan tingginya angka kejadian diare di desa tersebut. Perilaku masyarakat dalam mengkonsumsi air sebelum direbus sudah menjadi kebiasaan, karena menurut mereka air tersebut lebih segar dan dinilai lebih praktis dibanding harus di rebus terlebih dahulu.

Berdasarkan pernyataan diatas, maka perlunya alternatif pemecahan untuk menangani permasalahan mengenai pengelolaan air bersih yaitu dengan penyuluhan kepada masyarakat mengenai pentingnya mengelola air sebelum diminum, serta pembentukan kader sehat yang dapat mengubah serta memantau perkembangan perilaku dan sikap masyarakat akan pentingnya mengelola air sebelum digunkan.

\section{METODE}

Planning adalah proses dasar yang digunakan untuk memilih tujuan dan menentukan cara pencapaiannya. Merencanakan berarti mengupayakan penggunaan sumber daya manusia (human resources) dan sumber daya alam (natural resources) untuk mencapai tujuan. Perencanaan merupakan kegiatan maupun proses dalam membuat rencana yang kelak dipakai dalam rangka pencapaian tujuannya. Dalam kegiatan, kelompok banyak berhadapan dengan berbagai keterbatasan. Karena itu, dengan adanya rencana, diharapkan kegiatan lebih efektif serta efisien (Silviani, Pardede \& Sembiring, 2020).

Pada tahap ini, dalam melaksanakan kegiatan Pengalaman Belajar Lapangan (PBL) 
2 kelanjutan dari PBL 1 yang dilakukan oleh kelompok 1 RT 02 di Desa Simpang Warga Luar dilakukan secara daring. Pada kegiatan Pengalaman Belajar Lapangan (PBL) 1, memuat kegiatan wawancara kepada masyarakat terkait kesehatan yang kemudian dilakukan MTK dan FGD untuk menentukan permasalahan yang menjadi prioritas di desa tersebut. Kemudian pada PBL 2 dilakukan kegiatan berupa penyuluhan mengenai pentingnya pengelolaan air sebelum digunakan atau dikonsumsi kepada masyarakat Desa Simpang Warga Luar RT 02. Kegiatan tersebut dilakukan melalui Whatsapp Group warga Desa Simpang Warga Luar RT 02. Kegiatan penyuluhan yang dilakukan dimulai dari pembuatan Group dengan warga Desa Simpang Warga Luar RT 02. Langkah awal yang dilakukan yaitu pengumpulan kontak masyarakat sasaran yang akan di Intervensi. Kontak yang dikumpulkan adalah kontak yang terdaftar dalam whatsapp karena kegiatan dilaksanakan via grup whatsapp (WAG). Setelah dilakukan proses pengumpulan kontak masyarakat. para anggota kelompok menghubungi kontak yang didapatkan untuk perkenalan dan meminta izin ingin memasukkan ke dalam grup whatsapp. Setelah mendapatkan izin dari kontak yang dihubungi maka dilanjutkan dengan pembuatan grup whatsapp dengan nama "SWL RT 02" yang dibuat oleh ketua kelompok. Dalam grup tersebut terdapat warga Desa Simpang Warga Luar RT 02 sebanyak 15 orang, anggota kelompok 1 sebanyak 3 orang serta dosen pembimbing kelompok 24. Kemudian dilakukan rapat persiapan yang membahas terkait rangkaian kegiatan, metode kegiatan dan media kegiatan yang akan dilakukan pada kegiatan intervensi Pengalaman Belajar Lapangan (PBL) 2 ini. Setelah kelompok melakukan rapat persiapan, dilanjutkan dengan penyusunan dan pembuatan prepost, materi dan media yang selanjutnya dikonsultasikan kepada dosen pembimbing dan menunggu persetujuan. Persiapan terakhir yang dilakukan adalah penyusunan jadwal kegiatan intervensi Pengalaman Belajar Lapanga (PBL) 2 secara internal kelompok. Walaupun sudah ada timeline yang telah diberikan oleh tim UP PBL, penyusunan jadwal kegiatan ini diharapkan dapat meperlancar jalannya kegiatan.

Alur proses yang sudah direncanakan dalam kegiatan penyuluhan dengan menggunakan media berupa poster, booklet dan video yang berisi materi mengenai pengelolaan air sebelum digunakan atau dikonsumsi yaitu dengan dibagikan di grup whatsapp Desa Simpang warga luar agar masyarakat dapat membaca dan memahami mengenai isi materi tersebut. Setelah pemberian media, maka dilanjutkan dengan penyampaian materi secara singkat dan dilakukan diskusi seperti mempersilahkan para warga untuk bertanya apabila ada yang masih belum dipahami dari materi yang sudah disampaikan. Setelah rangkaian kegiatan penyuluhan selesai, kelompok 1 melakukan pemeriksaan pre dan post-test yang telah diisi oleh warga Desa Simpang Warga Luar RT 02. Setelah pemeriksaan pre dan post-test dilakukan, hal selanjutnya adalah cross check data, perekapan data, analisis data dan penyusunan laporan kegiatan PBL.

Monitoring dan evaluasi atau monev merupakan kegiatan yang ditujukan pada suatu program yang sedang atau sudah berlangsung yang bertujuan untuk melihat perkembangan masyarakat terhadap kegiatan yang dilakukan. Proses pengumpulan dan analisis informasi mengenai kegiatan program sehingga dapat dilakukan tindakan koreksi untuk menyempurnakan program atau kegiatan intervensi selanjutnya (Perdana, 2020). Evaluasi diperlukan untuk mengetahui tingkat perkembangan, kendala maupun permasalahan yang muncul dari terselenggaranya kegiatan yang nantinya dapat digunakan sebagai bahan pertimbangan kedepannya sehingga segala bentuk kedepannya dapat diantisipasi (Sahmad, 2019). Kegiatan monitoring dan evaluasi dilakukan pada saat kegiatan penyuluhan berlangsung dan setelah kegiatan penyuluhan selesai dengan cara pemantauan dan pengawasan terhadap proses, hasil dan dampak dari kegiatan penyuluhan yang dilakukan. Evaluasi dari program ini dapat dilihat dari meningkatnya pengetahuan sasaran terkait pentingnya pengelolaan air sebelum digunakan/dikonsumsi dengan menilai apakah pengetahuan yang telah dimiliki masyarakat dimanfaatkan secara efektif dan efisien dilihat dari hasil pre test dan post test yang telah diberikan.

\section{HASIL DAN PEMBAHASAN}

Kegiatan PBL (pengalaman belajar lapangan) yang di lakukan pengabdian kepada masyarakat yang di desa simpang warga luar bertempatan pada RT.02 dilaksanakan pada bulan November 2020. Kegiatan ini di lakukan secara daring via (WhatsApp Group) dengan nama SWL RT 2.

Berikut data yang di dapat setelah melakukan pengamatan dan hasil FGD (Focus Group Discussion) pada saat PBL 1 .

Tabel 1. Hasil yang didapatkan dari pengumpulan data pada tahap analisis masalah yaitu digambarkan pada tabel berikut: 


\begin{tabular}{ccccc}
\hline No & Permasalahan & Jumlah & $\begin{array}{c}\text { Persentase } \\
(\mathbf{\%})\end{array}$ & Keterangan \\
\hline \multirow{2}{*}{1.} & Sampah & $32 \mathrm{KK}$ & 64 & Di sungai \\
\cline { 3 - 5 } & & $14 \mathrm{KK}$ & 28 & Di bakar \\
\cline { 3 - 5 } & $4 \mathrm{KK}$ & 8 & Di kubur \\
\hline 2. & Jamban & $18 \mathrm{KK}$ & 36 & Layak \\
\cline { 3 - 5 } & & $32 \mathrm{KK}$ & 64 & Tidak Layak \\
\hline 3. & Air Bersih & $41 \mathrm{KK}$ & 82 & Baik \\
\hline & & $9 \mathrm{KK}$ & 18 & Kurang Baik \\
\hline & & $0 \mathrm{KK}$ & 0 & Tidak Baik \\
\hline
\end{tabular}

Berdasarkan tabel memperoleh 3 permasalahan, sehingga komunitas yang dibawa pada MTK I yaitu pembuangan dan pengelolaan sampah diperoleh sebanyak $32 \mathrm{KK}$ (64\%) dibuang ke sungai, $14 \mathrm{KK}(28 \%)$ dibakar, dan $4 \mathrm{KK}(8 \%)$ dikubur dalam tanah; jamban diperoleh sebanyak $18 \mathrm{KK}(36 \%)$ dengan kategori layak dan sebanyak 32 KK (64\%) dengan kategori tidak layak; serta data pengelolaan air bersih sebanyak $41 \mathrm{KK}(82 \%)$ masayarakat menggunakan air dengan kategori baik, 9 KK (18\%) dengan kategori kurang baik dan $(0 \%)$ dengan kategori tidak baik.

Setelah prioritas masalah didapat lalu dilakukan identifikasi masalah yang dilakukan di MTK 1, dimana di lakukan musyawarah dengan perwakilan warga desa mengenai permasalahan sampah, jamban dan air bersih. Dari hasil diskusi dengan warga, masyarakat memilih kejadian yang di angkat adalah permasalahan mengenai air bersih dikarenakan air merupakan sumber dari segala penyakit yang terjadi pada warga mereka mulai dari kejadian diare, gatal-gatal atau alergi.

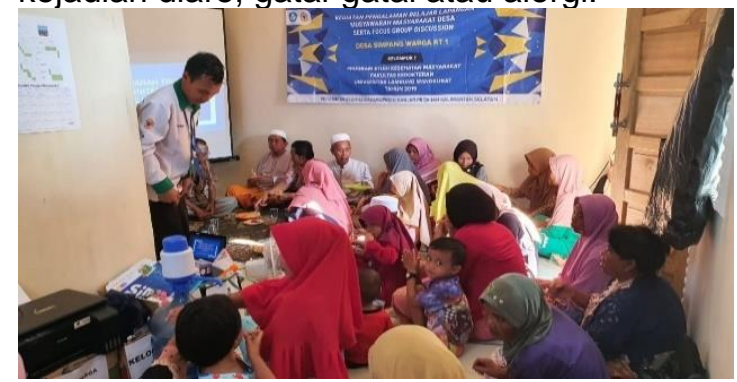

Gambar 2. Penentuan Prioritas Masalah oleh Warga

Faktor risiko yang didapat dari pengumpulan data ke 2 antara lain sebagai berikut:

Tabel 2. Faktor Risiko

\begin{tabular}{lllll}
\hline No & Pengetahua & Perilaku & Sarana dan & SDM \\
Prasarana & \\
\hline 1. & Belum & Banyak & Kurang & Masih \\
& adanya & masyarakat & tersedianya & kurangnya \\
penyuluhan & yang & air bersih & pemahama \\
dari Tenaga & menggunak & dan tenaga & n \\
& Kesehatan & an air & penyuluh & masyaraka \\
& & sungai & mengenai & t mengenai \\
& untuk & air & pengelola \\
& & kebutuhan & pengelolaan & an air \\
& sehari-hari & air bersih & bersih \\
\hline
\end{tabular}

\begin{tabular}{llll}
\hline 2. & Belum & Cukup & Kurang \\
& adanya & banyak & tersedianya \\
penyuluhan & yang & ledeng \\
dari Tenaga & langsung & umum untuk \\
Kesehatan & mengonsu & mendapatka \\
& msi air & n air bersih \\
& mentah & \\
\hline
\end{tabular}

Penentuan Prioritas Pemecahan dilakukan pada MTK 2 dengan menawarkan beberapa intervensi non fisik (pembentukan kader terlatih dan penyuluhan tentang pengelolaan air bersih) dan fisik (pembuatan ledeng umum. (Hasil dari MTK 2 didapat untuk intervensi fisik berupa pembentukan kader terlatih dan intervensi fisik adalah pembuatan ledeng umum.

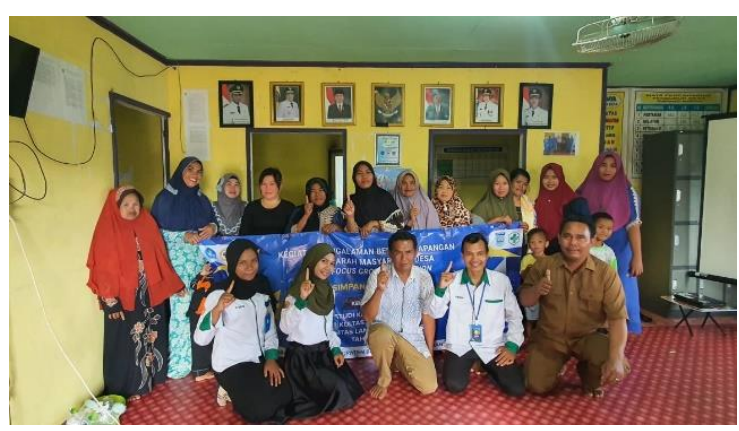

Gambar 3. Penetapan Prioritas Pemecahan Masalah dari Faktor Risiko yang di Dapat bersama Aparat Desa dan Warga.

Hasil yang didapatkan dari kegiatan Intervensi pada kegiatan Pre-Post test yang dilakukan dengan 15 peserta diketahui bahwa rata-rata masyarakat mengalami peningkatan, hasil tersebut menunjukan Pengetahuan Mengenai Pengelolaan Air Bersih sebanyak $83,2 \%$, Pada hasil pengetahuan mengenai pengelolaan air bersih meningkat $8,98 \%$ dan sikap pengelolaan air bersih 12,14\%. Meskipun demikian hasil tersebut masih belum memenuhi target luaran yaitu peningkatan sebanyak $75 \%$, hal ini dapat disebabka hasil Pre-post masyarakat sudah yang baik, sehingga tidak banyak mengalami peningkatan.

Peserta kegiatan penyuluhan berjumlah 15 orang dan dari berbagai golongan usia dan jenis kelamin. Distribusi jenis kelamin peserta penyuluhan dapat dilihat pada Tabel1 berikut.

Tabel 3. Distribusi dan Frekuensi Jenis Kelamin Peserta Penyuluhan

\begin{tabular}{ccc}
\hline Jenis Kelamin & Frekuensi & Persentase (\%) \\
\hline Laki-laki & 4 & 26,7 \\
\hline Perempuan & 11 & 73,3 \\
\hline Jumlah & 15 & 100
\end{tabular}

Sebelum penyampaian materi dilakukan peserta akan diberikan pre-test terlebih dahulu. Setelah semua materi disampaikan selanjutnya diberikan post-test 
untuk melihat ada tidaknya perubahan nilai pengetahuan, sikap dan perilaku peserta. Pretest dan post-test diberikam dalam bentuk google form yang berisi pertanyaan untuk mengukur pengetahuan, sikap dan perilaku peserta.

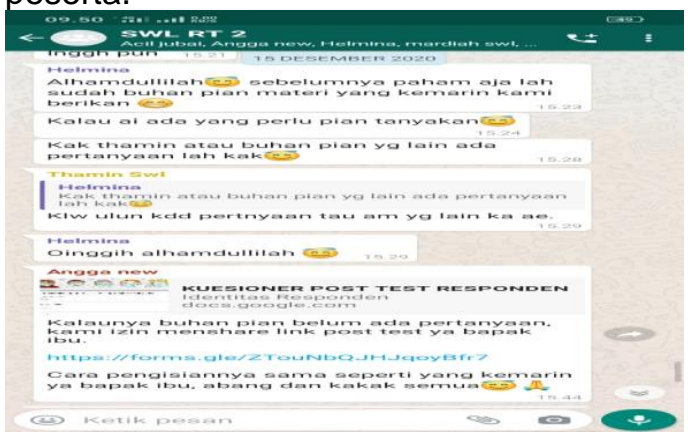

Gambar 4. Penyebaran Link Google Form melalui WhatsApp

Materi disampaikan dalam bentuk audio visual yaitu berupa video yang dibuat oleh panitia kegiatan. Materi terbagi ke dalam video tentang pengelolaan air bersih, templet tentang konsep air bersih dan tambahan berupa poster tentang sebaran kasus covid-19. Video dikirimkan secara berkala yakni setiap 12 minggu sekali. Hal ini bertujuan agar peserta dapat lebih mudah dalam mencerna informasi yang didapat. Penyampain di dalam video dibuat dengan bahasa yang sesederhana mungkin dan setiap video yang dikirimkan akan diberikan penjelasan singkat dari panitia terkait isi videonya.

Hasil penelitian membuktikan pengetahuan warga tentang pengelolaan air bersih mengalami perbedaan, namun tidak begitu signifikan setelah diadakannya penyuluhan. Hal ini menunjukkan adanya pengaruh penyuluhan terhadap pengetahuan yang kemudian dianalisis secara statistik dengan menggunakan uji wilcoxon. Hal ini dapat terjadi karena pada saat peyuluhan, pemateri memberikan materi yang mudah dimengerti oleh masyarakat. Masyarakat sudah dapat membedakan dampak yang akan terjadi jika tidak menggunakan air yang tidak bersih, sehingga mengenai pemahaman dan pengetahuan masyarakat sudah baik.

Hasil evaluasi dari intervensi kegiatan yang dilaksanakan di Desa Simpang Warga Luar RT 02 meliputi evaluasi input, proses dan output sebagai berikut: Evaluasi Input adalah tersedianya sarana dan prasarana dalam pelaksanaan kegiatan intervensi. Sarana yang tersedia dari persiapan pembuatan materi hingga proses kegiatan intervensi yang meliputi laptop, smartphone, maupun aplikasi WhatApps. Penggunaan media promosi kesehatan tentang pentingnya pengelolaan air bersih dengan booklet, video animasi dan poster yang berisi informasi yang didukung dengan sumber literature yang akurat dan dapat dipercaya serta partisipasi masyarakat yang ada didalam grup WhatsApp walaupun untuk keaktifan masyarakat dapat terbilang pasif. Evaluasi proses dilakukan pada saat kegiatan berlangsung oleh pelaksana kegiatan. Pelaksanaan intervensi berupa penyuluhan di grup WhatsApp dilakukan pada tanggal 2 Desember dan 4 Desember 2020. Evaluasi jangka pendek dengan pemberian kuesioner melalui pre dan post test. Pada saat penyuluhan keaktifan peserta bersifat pasif namun masih dapat diatasi dengan berperan aktif mahasiswa selama proses penyuluhan sehingga dapat mempermudah jalannya acara penyuluhan mengenai pengelolaan air. Output dari kegiatan intervensi penyuluhan yang dilakukan adalah meningkatnya pengetahuan untuk menangani permasalahan lingkungan agar masyarakat tahu mana tindakan yang benar dan mana yang belum tepat, baik itu terkait pentingnya penggunaan air bersih, pengelolaan air sebelum minum.

\section{SIMPULAN DAN SARAN}

Kegiatan PBL yang dilakukan di desa Simpang Warga Luar berjalan dengan lancar dan memperoleh peningkatan dari hasil pre dan post-test. Masyarakat setelah diberikan pengetahuan dan informasi yang luas mengenai pengelolaan air bersih dapat menerima dan memahami dengan tingkatan pengetahuan yaitu pada pre test masyarakat masih banyak yang menjawab salah setelah diberikan lagi edukasi dan pengulangan materi, masyarakat bisa menangkap informasi yang kami berikan dan banyak menjawab soal dengan benar. Banyaknya masyarakat yang ikut berpartisipasi, Masyarakat juga aktif dalam bertanya tentang materi dan edukasi mengenai pengelolaan air bersih. Dari hasil yang diidapat dengan uji Wilcoxon pada pretest dan posttest pengetahuan mengenai pengelolaan air bersih didapatkan nilai uji 0.014 yaitu $<0.05$ artinya $\mathrm{Ho}$ ditolak dan $\mathrm{H} 1$ diterima artinya ada perbedaan yang signifikan antara pengetahuan mengenai pengelolaan air bersih pada saat pengisian kuesioner sebelum dan sesudah intervensi. Saran kepada peserta kegiatan agar pengetahuan yang didapat dalam kegiatan pengabdian ini dapat diterapkan di kehidupan sehari-hari agar terhindar dari dampak-dampak yang muncul akibat hipertensi yang dibiarkan.

\section{UCAPAN TERIMAKASIH}

Ucapan terimakasih kami sampaikan kepada berbagai pihak, diantaranya kepada pihak kampus kami Program Studi Kesehatan Masyarakat Fakultas Kedokteran Universitas 
Lambung Mangkurat dan kepada seluruh masyarakat yang telah berkenan mengikuti rangkaian kegiatan penyuluhan dari kami sehingga berjalan dengan baik dan lancar.

\section{DAFTAR RUJUKAN}

Irawan, H. T., Pamungkas, I. and Arhami (2018) 'Analisis Lean Service Untuk Mengurangi Waste Pada Perusahaan Daerah Air Minum (PDAM) Tirta Mountala Aceh Besar', Jurnal Optimalisasi, 4(2), pp. 70-77.

Latief, R. (2019) 'Jurnal Ecosystem Volume 19 , Nomor 1 , Januari - April 2019 Jurnal Ecosystem Volume 19 , Nomor 1 , Januari - April 2019', Jurnal Ecosystem, 19(April), pp. 109-116.

Noor, A., Supriyanto, A. and Rhomadhona, H. (2019) 'Aplikasi Pendeteksi Kualitas Air Menggunakan Turbidity Sensor dan Arduino Berbasis Web Mobile', Jurnal CorelT, 5(1), pp. 13-18.

Pontororing, M. E. I., Pinontoan, O. R. and Sumampouw, O. J. (2019) 'Uji Kualitas Air Bersih Dari PT. Air Manado Berdasarkan Parameter Biologi dan Fisik di Kelurahan Batu Kota Kota Manado', JurnalKesmas, 8(6), pp. 484492.

Saputra, A. P. and Nur, M. I. (2019) 'Manajemen Kinerja Kelembagaan dalam Meningkatkan Kualitas Air Bersih pada Perusahaan Daerah Air Minum', Jurnal Birokrasi \& Pemerintahan Daerah, 1(November), pp. 1-18.

Silviani, I., Pardede, I. F. and Sembiring, D. C. (2020) 'Komunikasi Krisis Dalam New Normal', Jurnal Massage Komunikasi, 9(1), pp. 82-87.

Sahmad. (2019). Sistem monitoring dan evaluasi kegiatan belajar mengajar (emovev kbm) berbasis web (studi kasus universitas teknologi sumbawa. Phd thesis. Universitas Teknologi Sumbawa.

Perdana, Kresna, Bayu, et al. (2020). Pendidikan karakter pada anak asuh dalam program family based care di sos children's village semarang. Phd thesis. Unnes. 